\title{
床衝撃音遮断性能評価量の相関 ACTUAL SITUATION OF 関係に関する実態把握 CORRELATION ABOUT FLOOR IMPACT SOUND INSULATION RATING
}

\author{
鹿倉潤二— $* 1$ 井上勝夫 — $* 2$ \\ 天川恭—— $* 3$ 大川周一郎—— $* 4$ \\ 大川平一郎—— $* 5$ \\ キーワード : \\ 床衝撃音，A 特性床衝撃音レベル，単一数值評価量
}

Keywords:

Floor impact sound, A-weight floor impact sound level, Single-number quantity

\author{
Junji SHIKAKURA — $* 1$ \\ Kyouichi AMAKAWA - $* 3$ \\ Heiichiro OHKAWA —— $* 5$
}

\section{1.はじめに}

建築物の空間性能を表す色々な評価尺度・評価規準は、実空間に 居住する居住者が感じる生活実感と対応し、その変化を明確に表す ことのできるものでなければならない。子供の飛び跳ねに代表され る衝撃時間が比較的長い重量床衝撃系騒音の場合、その性能測定法 に標準重量衝撃源として衝撃力特性（1）（タイヤ）（以下、タイヤ ${ }^{1}$ と表記）が導入され、 $\mathrm{L}$ 等級曲線による単一数值評価法（以下、 $\mathrm{L}$ 等級評価）が定着している。これらの、測定および評価法は日本工 業規格のみならず品確法や各種協会規準等にも導入され、広く浸透 している。また、最近では同評価尺度・評価基準値と居住者の長期 に亘る生活実感との対応性の高いことが改めて検証 ${ }^{2,3}$ れるなど妥 当性も示されている。

一方、2000 年の JIS A 1418 の改正に伴い、標準重量衝撃源とし て追加導入された衝撃力特性（2）（ボール）（以下、ボールと表記） を用いた A 特性床衝撃音レベル（以下、A 特性と表記）によって重 量床衝撃音遮断性能を評価する方法も検討されている イヤに比べ衝撃力がかなり小さく、ハンドリングも良いことから測 定法や評価法が整い居住者反応との対応性が検証されれば、有用な 標準重量衝撃源と位置づけられる。しかし、ボール加振時の A 特性 評価を導入するとしても、今までタイヤで測定した膨大なデータと の関連性を検証し確立しておく必要がある。同様にボール加振時の $\mathrm{A}$ 特性の床衝撃音レベル予測計算方法の検証も設計上重要な要件で あり、タイヤを用いた $\mathrm{L}$ 等級評価を基準とした性能表示制度や、金 融公庫、デベロッパーの基準等への対応も無視することはできない。

これらの状況を考慮すると、図 1 に示すように今まで蓄積された タイヤ加振時の $63 \sim 500 \mathrm{~Hz}$ の重量床衝撃音データとボール加振時の
$\mathrm{A}$ 特性床衝撃音レベルとの互換性および相互の読み替え方法などの 十分な検討・検証実験が必要と考えられる。

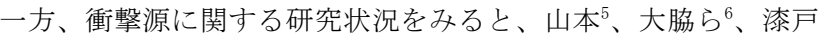
ら $7^{7}$ 衝撃源の違いによる床衝撃音レベルの変化について検証し、タ イヤ加振時の $\mathrm{L}$ 等級からボール加振時の $\mathrm{L}$ 等級への変換は、コンク リート構造裸床の場合は衝撃力レベル差を補正することで対応し、 乾式二重床施工後の床構造の場合には $31.5 、 63 \mathrm{~Hz}$ 帯域の夕相関が良 いという結果を示し、乾式二重床の衝撃力に対する非線形性を指摘 している。

また、中澤ら ${ }^{8}$ 、稲留 ${ }^{9} 、$ 田中ら ${ }^{10}$ 、漆戸ら ${ }^{11}$ は $\mathrm{L}$ 等級評価と $\mathrm{A}$ 特 性評価の相関や、帯域別床衝撃音レベルをバンド合成して A 特性を 算出する方法に関する検討を行っている。その結果、タイヤおよび ボールのどちらの衝撃源においても騒音計の周波数重み特性 A を通 して直接測定した值（以下、A 特性 AP 值）と、周波数重多特性 A を 通して測定した 31.5〜 500Hz 帯域のバンド合成した值の相関が良い ことを示している。また、A 特性 AP 值と L 数の相関に関しては、L 等級評価を $31.5 \mathrm{~Hz}$ 帯域まで拡張することによって A 特性 AP 值と L 数の相関が良くなることを報告しているが、文献 8 および 9 におけ る検討は同一スラブ内の 1 打撃点 1 受音点のデータが大半であり、 スラブの種類変化が少なく居室の空間性能の対応を検証していると は言い難い。特に受音室のモードの影響を強く受ける $63 \mathrm{~Hz}$ 帯域を評 価対象とするのであれば、多数の受音室の平均床衝撃音レベルで比 較する必要がある。

そこで本報では、最近 10 年以内に竣工したできるだけ多くの集合 住宅を対象として、タイヤ、ボールおよびタッピングマシンを用い た場合の $\mathrm{L}$ 等級評価と $\mathrm{A}$ 特性評価を比較し、それぞれの相関関係を

\begin{tabular}{|c|c|c|c|}
\hline${ }^{*} 1$ & $\begin{array}{l}\text { (株)栗本鐵工所 } \\
(\text { 干 } 108-0075 \text { 東京都港区港南 2-16-2) }\end{array}$ & ${ }^{* 1}$ & KURIMOTO, Ltd. \\
\hline *2 & 日本大学理工学部＼cjkstart教授・工博 & ${ }^{*} 2$ & $\begin{array}{l}\text { Prof., Dept. of Architecture, College of Science and Technology, NIHON Univ., } \\
\text { Dr. Eng. }\end{array}$ \\
\hline${ }^{*} 4$ & (株)周音響計測 & ${ }^{*} 4$ & Shyu Sound Environment Research Inc. \\
\hline${ }^{*} 5$ & (株住環境総合研究所 工博 & ${ }^{*} 5$ & Housing Environment Research Institute Inc., Dr. Eng. \\
\hline
\end{tabular}


空間性能として検討することとし、今後の測定法、評価法の検討に 供することとした。

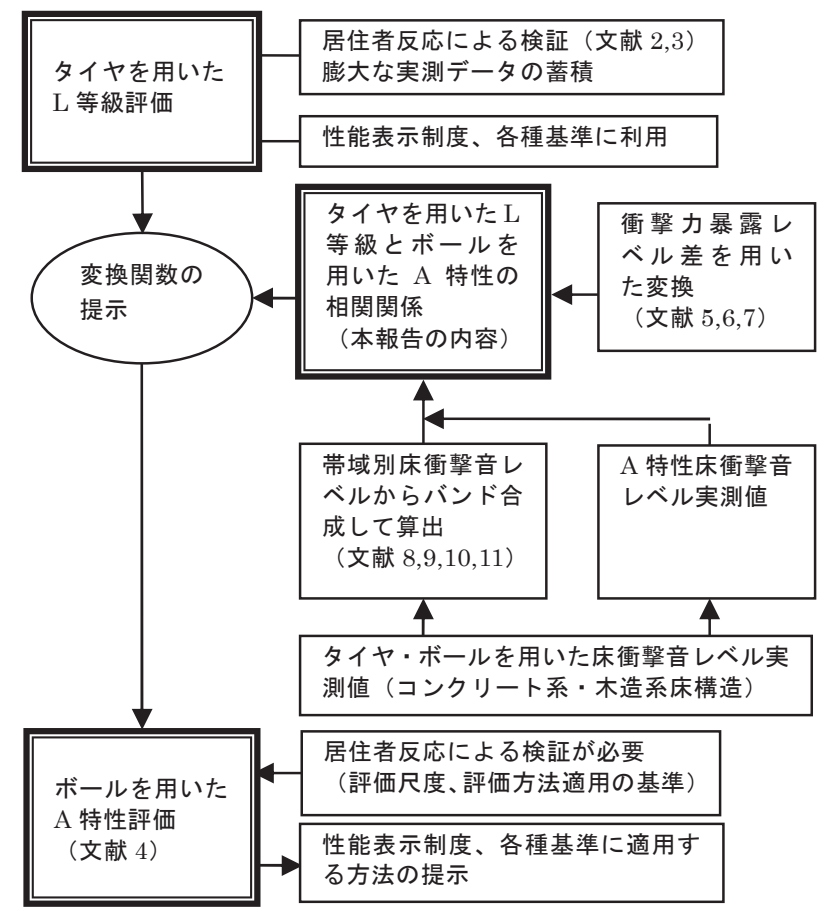

図 1 評価值の変更に関わる必要検討項目・流れ

\section{2. 測定対象床構造及び測定方法}

測定対象居室数を表 1 に示す。測定対象の床構造は RC 及び SRC 造のスラブで、厚さ $200 \mathrm{~mm} \sim 300 \mathrm{~mm}$ 、面積は概ね 20〜 $100 \mathrm{~m}^{2}$ の範囲 (50 〜 $100 \mathrm{~m}^{2}: 80 \%$ ) である。衝撃源変化に対する加振点および測定点は、 各室とも同一点で行なうこととし、測定は JIS A 1418-1、2 に準拠 して行なった。衝撃源にはタイヤ、ボール、タッピングマシンを用 い、測定は 5 点打撃 5 点受音を基本とした。

尚、表 1 の測定状況に示す中間とは、施工途中の居室での測定で あり、音源側のスラブは裸床であるが、受音側は間仕切壁まで施工 が完了した状態である。天井は設置されていない場合が殆どであり、 受音室の開口部は石膏ボード等の仮設部材で塞いだ状態である。ま た、竣工時の床仕上げ構造は、設計目標值の $\mathrm{L}_{\mathrm{rL}}-45$ を満足できるも のが選定され施工されている。そのため、物件ごとに床仕上げ材の 仕様が異なるため、今回の検討では直張床、二重床、裸床の 3 分類 のみで比較することとした。

\section{表 1 測定物件数}

\begin{tabular}{|c|c|c|}
\hline 測定状況 & 床仕上げ構造 & 測定数 \\
\hline \hline \multirow{2}{*}{ 竣工 } & 直張床 & 137 \\
\hline & 二重床 & 193 \\
\hline 中間 & 裸床 & 153 \\
\hline \multicolumn{2}{|c}{} & 483 \\
\hline
\end{tabular}

\section{3. 各種衝撃源別の $\mathrm{L}$ 等級評価と $\mathrm{A}$ 特性評価の対応}

ここでは、A 特性評価を利用する上での問題点を検討することと した。A 特性評価と $\mathrm{L}$ 等級評価の相関については文献 8 および 9 の 検討以前にも、「建物の遮音性能基準と設計指針 ${ }^{12} 」 て ゙$ 検証されてお
り、重量床衝撃音レベルに関しては $\mathrm{A}$ 特性の值が $\mathrm{L}$ 数よりも $2 \mathrm{~dB}$ 大 きくなる傾向で相関が良く、軽量床衝撃音レベルの場合はほぼ等し い值になることが示されている。しかし、当時の床構造と近年の床 構造では傾向が異なる可能性もあるため、最近の測定データを用い て、それぞれの衝撃源に対する $\mathrm{L}$ 等級評価と $\mathrm{A}$ 特性評価の対応を検 討することとした。こで用いた A 特性評価の值は A 特性 AP 值であ り、 $\mathrm{L}$ 等級評価は $\mathrm{L}$ 数を用いることとした。

タイヤ加振時の結果を図 2 に、ボール加振時の結果を図 3 に、タ ッピングマシン加振時の結果を図 4 に示す。ここで、グラフ中でデ ータが重なる場合には、図中の凡例で示すようにデータ数に応じて 大きさを変えて表すこととした。

図 2 に示寸タイヤ加振時の場合は、傾きが緩やかであり $\mathrm{L}$ 等級評 価に比べ $\mathrm{A}$ 特性評価は性能分解能が低くなる傾向にあることが分か る。しかし、図 3 および図 4 のボール加振時およびタッピングマシ ン加振時においては両者とも決定係数が 0.8 以上で、傾きが 0.9 程 度になっていることから、L 等級評価と A 特性評価はほぼ等しい結 果になり、どちらの評価量でも同程度の性能変化を表すことができ ると言える。

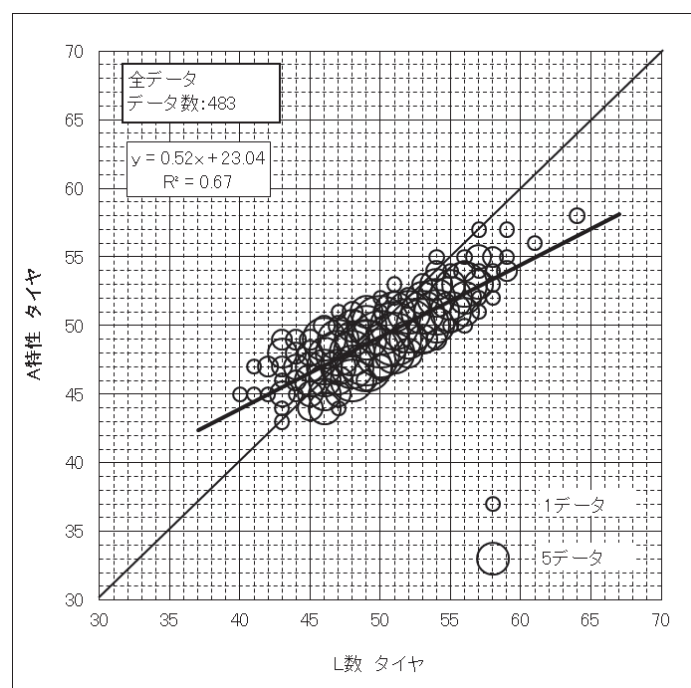

図 $2 L$ 数と $A$ 特性の比較（タイヤ加振時：竣エ・中間)

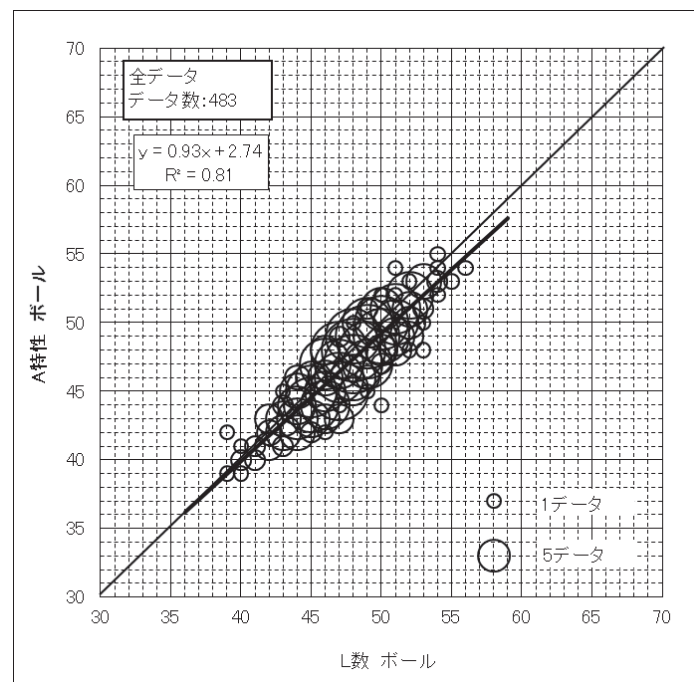

図 $3 \mathrm{~L}$ 数と $A$ 特性の比較（ボール加振時：竣エ・中間） 


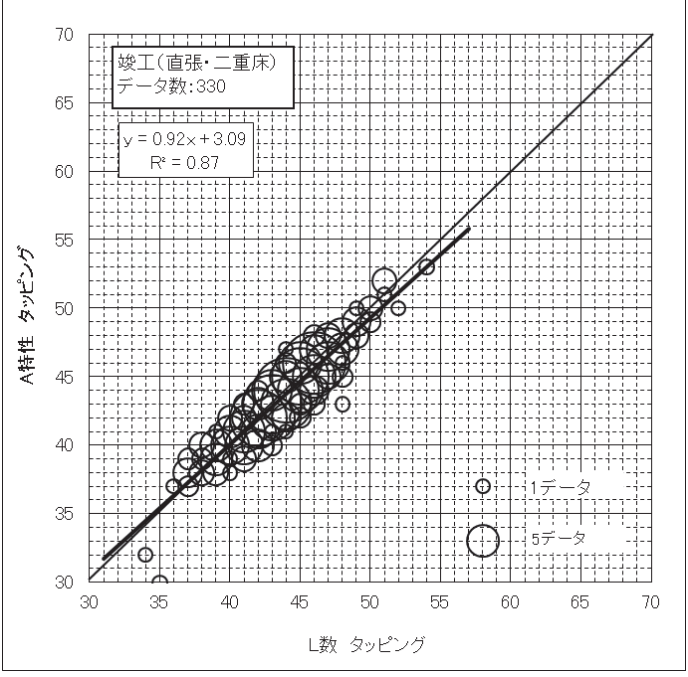

図 $4 \mathrm{~L}$ 数と $\mathrm{A}$ 特性の比較

(タッピングマシン加振時：竣エ)

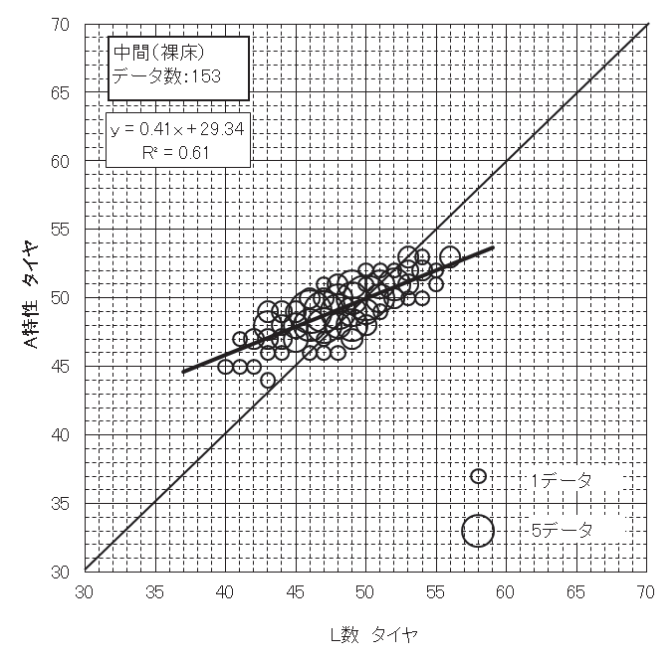

図 $5 \mathrm{~L}$ 数と $A$ 特性の比較 (タイヤ加振時 : 中間)

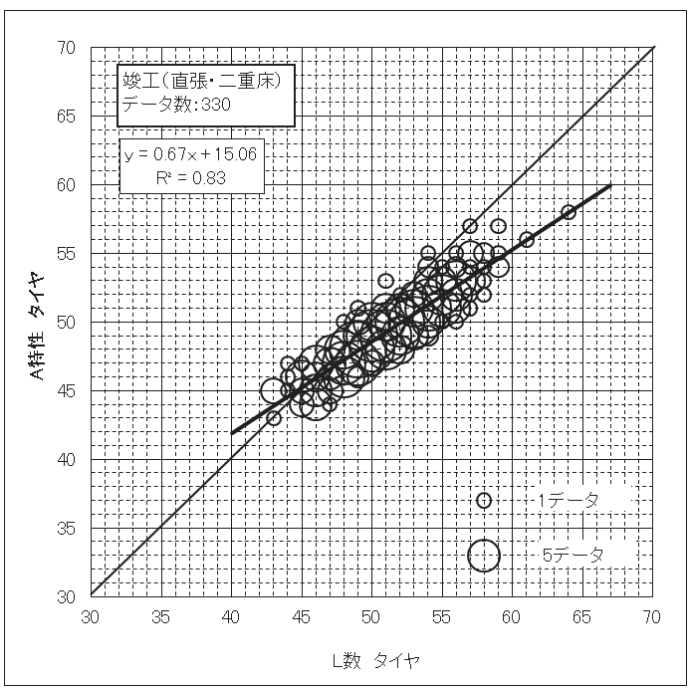

図 $6 \mathrm{~L}$ 数と $\mathrm{A}$ 特性の比較 (タイヤ加振時：竣工)
タイヤの場合は、L 等級評価の向上のための対策（剛性・質量の 増加、拘束性の増大など) によって $63 \mathrm{~Hz}$ 帯域以下の床衝撃音レベル は顕著に低下寸るが、125Hz 以上ではそれ程低下はないと考えられ る。そのため、接線法で評価する $\mathrm{L}$ 等級評価の場合には、 $\mathrm{L}$ 数の值 は低下寸るが、A 特性 AP 值は L 数程は低下しない。この傾向は図 5 および図 6 をみても明らかであり、特に中高周波数の減衰要素が少 ない裸床の場合に顕著である。

そこで、裸床におけるタイヤ加振時の $\mathrm{A}$ 特性補正後の音圧レベル 周波数特性を求めてみると図 7 のようになる。尚、ここでは図 5 で用いた $\mathrm{A}$ 特性の值を $47 \mathrm{~dB}$ 末満、 $47 \mathrm{~dB}$ 以上 $52 \mathrm{~dB}$ 未満、 $52 \mathrm{~dB}$ 以上の 3 つに分割し、それぞれの帯域別平均值として示した。

図 7 を見ると $63 \mathrm{~Hz}$ 帯域が主成分であり L 数は $63 \mathrm{~Hz}$ で決定される が、A 特性の值が小さくなった場合（ $47 \mathrm{~dB}$ 未満）には、63〜 $500 \mathrm{~Hz}$ でほぼフラットな周波数特性となるため、A 特性評価值に対する $125 \mathrm{~Hz}$ 帯域以上の成分の影響が大きくなることが分かる。

また、周波数帯域別のレベル変化（低下）状況を見ると、63Hz 帯 域では $10 \mathrm{~dB} 、 500 \mathrm{~Hz}$ 帯域では $5 \mathrm{~dB}$ 程度であり周波数が高くなるにつ れて低下量が低くなる傾向があり、この変化が図 5 の低レベル範囲 (性能の良い範囲) に表れているものと考えられる。しかし、裸床 の場合は施工途中の中間検查であるため、低レベル範囲（性能の良 (範囲）の $250 \mathrm{~Hz}$ 帯域以上においては暗騒音の影響で床衝撃音レ心゙ ルが小さくならなかった可能性も考えられるが、実測時の暗騒音レ ベルは床衝撃音レベルに比べ $10 \mathrm{~dB}$ 以上小さいことを確認している。

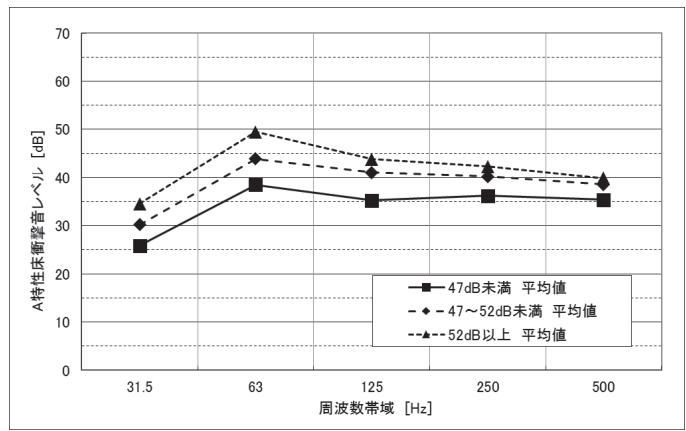

図 7 A 特性の周波数特性（タイヤ加振時 裸床）

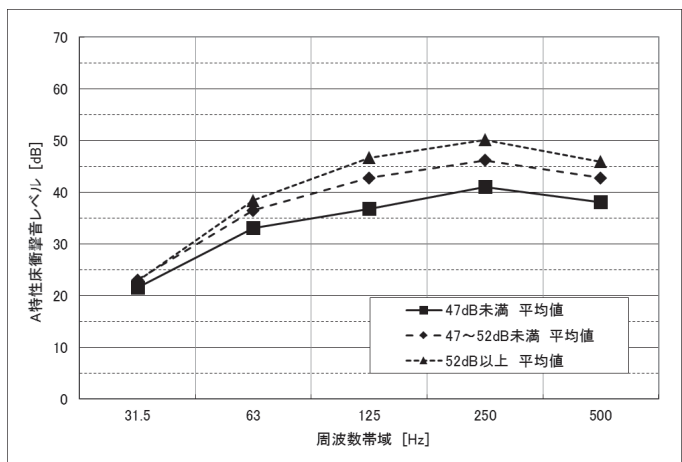

図 8 A 特性の周波数特性（ボール加振時 裸床）

表 2 衝撃力暴露レベル周波数特性 (dB ref·1N)

\begin{tabular}{|c|c|c|c|c|c|}
\hline & 31.5 & 63 & 125 & 250 & 500 \\
\hline \hline タイヤ & 47.0 & 40.0 & 22.0 & 11.5 & 5.5 \\
\hline \hline ボール & 39.0 & 31.0 & 23.0 & 16.0 & 11.5 \\
\hline \hline 差 & -8.0 & -9.0 & +1.0 & +4.5 & +6.0 \\
\hline
\end{tabular}




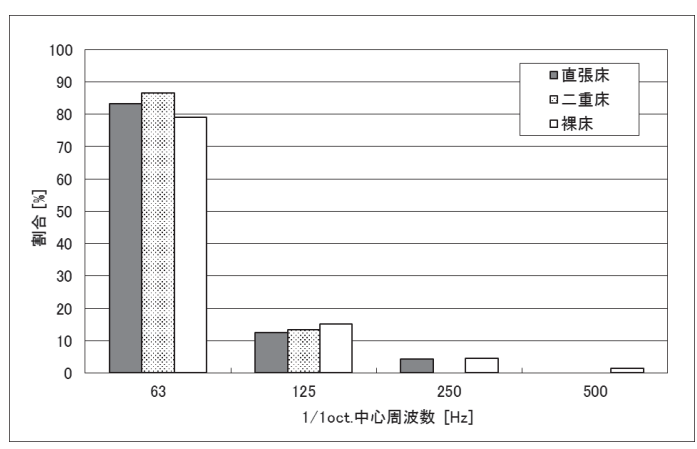

図 9 A 特性の主成分周波数帯域（タイヤ加振時）

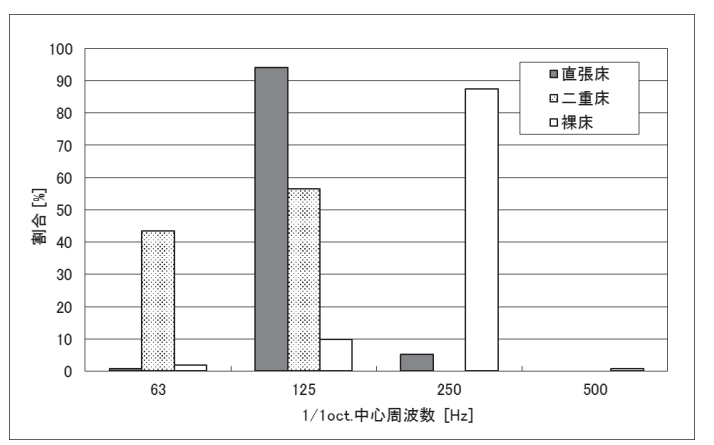

図 10 A 特性の主成分周波数帯域（ボール加振時）

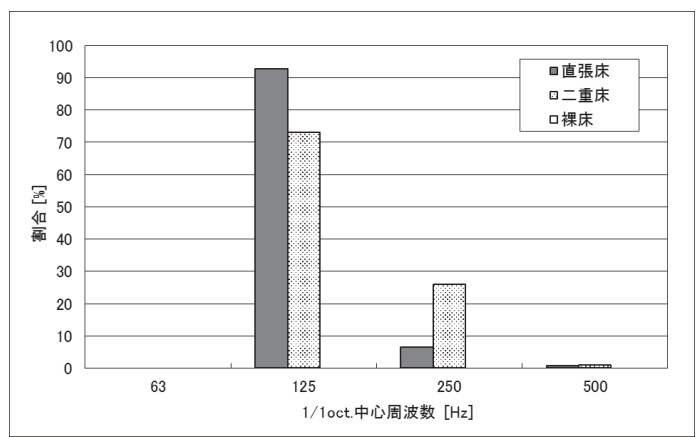

図 $11 A$ 特性の主成分周波数帯域（タッピングマシン加振時）

次に、裸床におけるボール加振時の $\mathrm{A}$ 特性補正後の音圧レベル周 波数特性を図 8 に示す。ボールの物性は低周波数域の衝撃力が小さ く、衝撃力特性 ${ }^{13}$ としては $125 \sim 500 \mathrm{~Hz}$ の成分がタイヤを上回る（表 2)。その結果、 $250 \mathrm{~Hz}$ 帯域が A 特性および $\mathrm{L}$ 数を決定する主成分と なり、低レベル範囲（性能の良い範囲）においても、図 3 に示すよ うに両者の対応が良くなっているものと考えられる。このように、 ボール加振時の場合は $250 \mathrm{~Hz}$ 帯域付近（125～500Hz）の影響が A 特 性 AP 值による性能を大きく左右してくることになる。

そこで、それぞれの衝撃源における A 特性の主成分となる周波数 帯域を仕上げ構造ごとに求め図 9〜図 11 に示す。図 9 に示す夕イ ヤ加振時の場合では、直張床、二重床および裸床のいずれの場合も 同様の傾向であり、63Hz 帯域が主成分になるものが 70〜 80\%であっ た。一方ボール加振時の場合は、裸床の場合は $250 \mathrm{~Hz}$ 帯域が主成分 になったのが $90 \%$ 以上であったが、直張床の場合は $125 \mathrm{~Hz}$ 、二重床の 場合は $63 \mathrm{~Hz}$ および $125 \mathrm{~Hz}$ が主成分となる傾向となり、仕上げ構造に より主成分となる周波数帯域が変化する。
また、タッピングマシン加振時の場合は、 $125 \mathrm{~Hz}$ 帯域が主成分と なる傾向で、特に直張床の場合には、ボール加振時およびタッピン グマシン加振時いずれも $80 \%$ 以上で $125 \mathrm{~Hz}$ 帯域が主成分となり、ボ ール加振時の場合と対応が良い。

以上のように、 L 等級評価と $\mathrm{A}$ 特性評価はタイヤ加振時の低レ心゙ ル範囲（性能の良い範囲）で、中高周波数帯域の成分の影響で $\mathrm{L}$ 数 に比べ $\mathrm{A}$ 特性の值の方が大きくなる傾向がある。また、タイヤ加振 時は床仕上げ構造に関係なく $63 \mathrm{~Hz}$ 帯域が主成分となるような評価 をしているが、ボール加振時の場合は床仕上げ構造により主成分と なる周波数帯域が異なる傾向となった。

このように、衝撃源や評価量を変えることによって単一数值評価 量に影響する周波数成分が変わるため、それぞれの衝撃源・評価量 が床のどのような性能を求め、何を評価しようとしているのかを十 分に検討しておく必要がある。

\section{4. ボール加振時の $\mathrm{A}$ 特性評価とタイヤ加振時の $\mathrm{L}$ 等級評価の比較}

本項では、床仕上げ構造別に、ボール加振時の A 特性評価とタイ ヤ加振時の $\mathrm{L}$ 等級評価を比較しボール加振時の A 特性評価の位置づ けを検討する。

両者の比較結果を図 12〜図 14 に示す。

図 12 の直張床および図 14 の裸床の場合、タイヤ加振時の L 数と ボール加振時の A 特性は、数值的な差が \pm 5 に入る割合がどちらの 場合も $90 \%$ 程度となりほぼ等しい值を示すが、決定係数はどちらも 0.1 程度であり相関が悪い。これは、前項の図 9 および図 10 に示 すように主成分となる周波数帯域が異なることが原因であり、その 要因の一つは、タイヤとボールの衝撃力周波数特性が異なるためで ある。

一方、図 13 の二重床の場合には、若干ではあるが、相関が良く なる傾向にある。これは、前項の図 9 および図 10 に示すように、 二重床の場合の主成分となる周波数帯域がタイヤ加振時と同じ $63 \mathrm{~Hz}$ 帯域になる割合が多くなったためと考えられる。しかし、数值 的にはボール加振時の A 特性の方が $5 \sim 10 \mathrm{~dB}$ 程度小さくなる傾向を 示している。これは、63Hz 帯域が主成分となる場合では表 2 に示寸 衝撃力レベル差の影響と考えられ、 $125 \mathrm{~Hz}$ 帯域以上が主成分となる 場合では既往研究で指摘されているように、二重床の衝撃力に対す る非線形性の影響と考えられる。

次に、ボール加振時の A 特性評価とタイヤ加振時の $\mathrm{L}$ 等級評価の ばらつきを比較するため、図 12〜図 14 で用いた実測值を床仕上げ 構造ごとに平均し、各図の下段に示すような正規分布を仮定して実 測值の $90 \%$ 含まれる範囲とそれぞれの平均值を比較してみると、 図 15 の様になる。いずれの床仕上げ構造でもタイヤ加振時の L 数 に比ベボール加振時の A 特性の $90 \%$ レンジ幅の方が狭くなっており

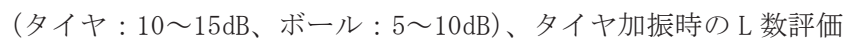
の方が性能変化を広く表現していることがわかる。さらに、文献 2 および 3 で示すように、床衝撃系騒音に対する長期生活時の居住者 反応（満足度や聞こえる程度）とＬ值評価が非常に良く対応してい ることを考えると、ボールを用いた A 特性による評価の適正性が心 配される。今後、実際の生活においてどちらが居住者反応と対応す るか検証する必要がある。 

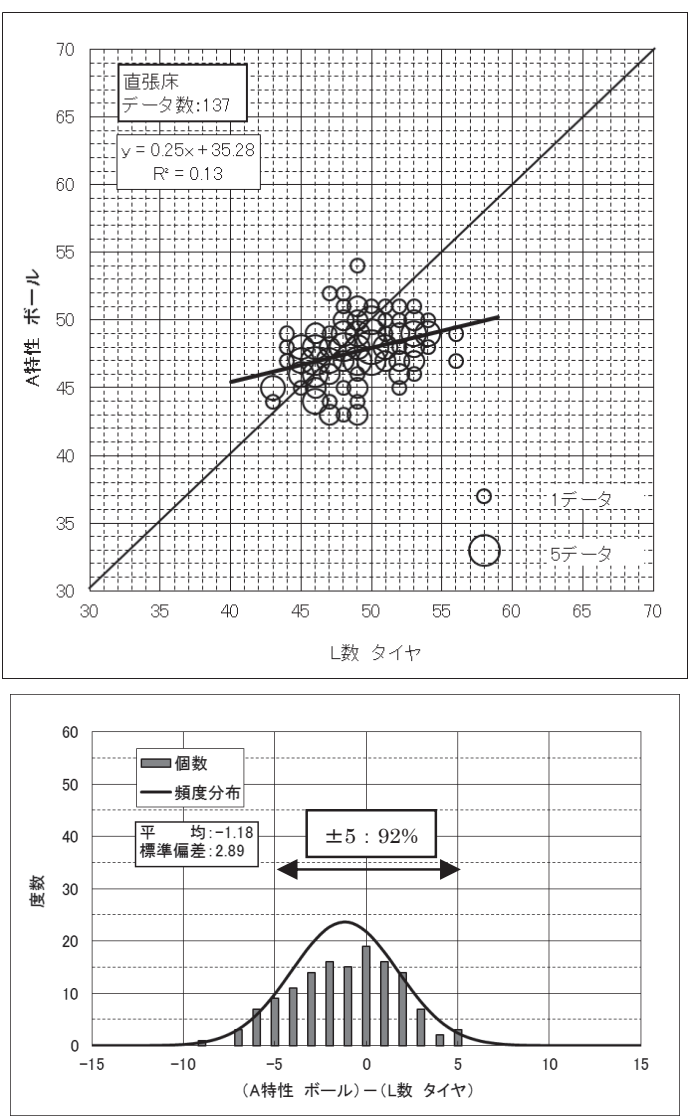

図 12 タイヤ加振時 ( $\mathrm{L}$ 数) と ボール加振時 (A 特性) の比較 (直張床)
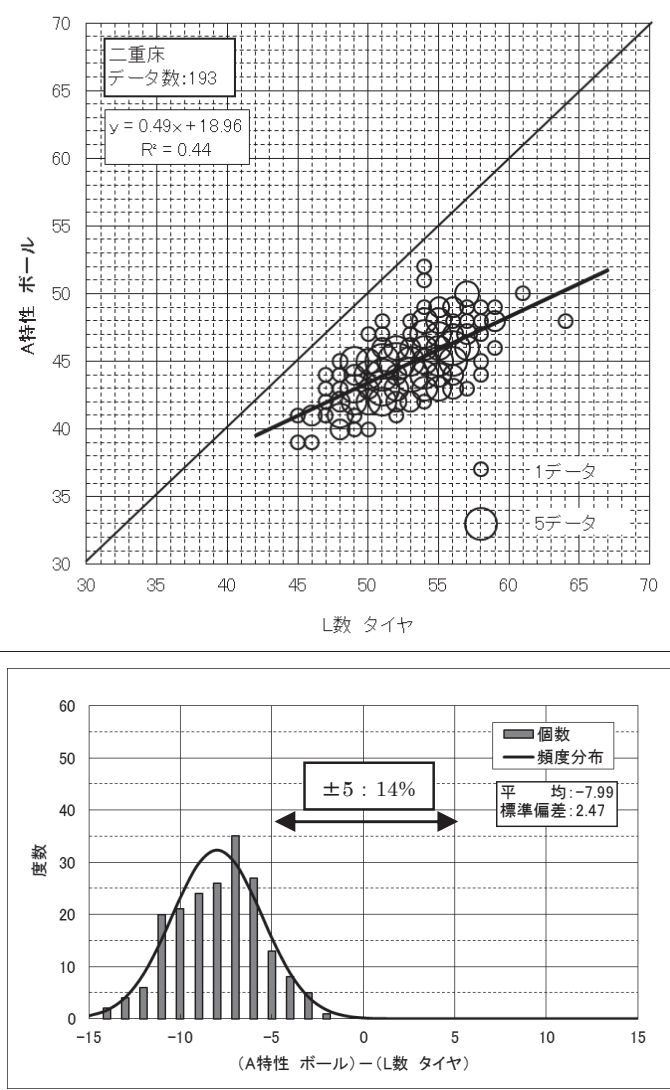

図 13 タイヤ加振時（ $\mathrm{L}$ 数）と ボール加振時（A 特性）の比較（二重床）
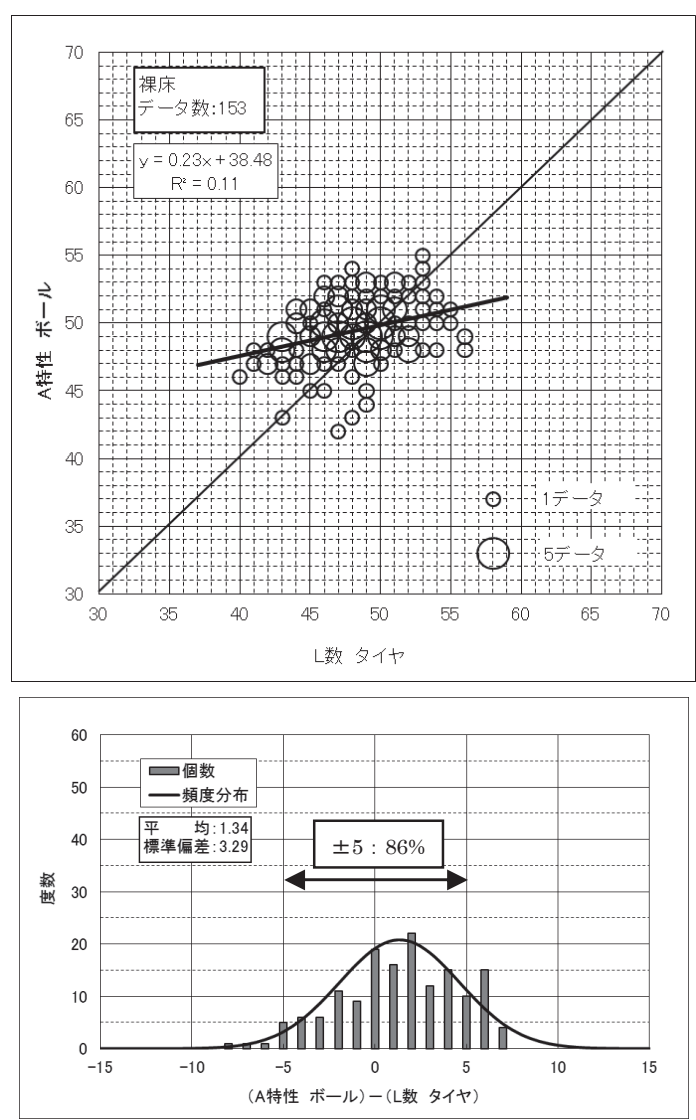

図 14 タイヤ加振時 ( $L$ 数) と

ボール加振時 (A 特性) の比較（裸床）

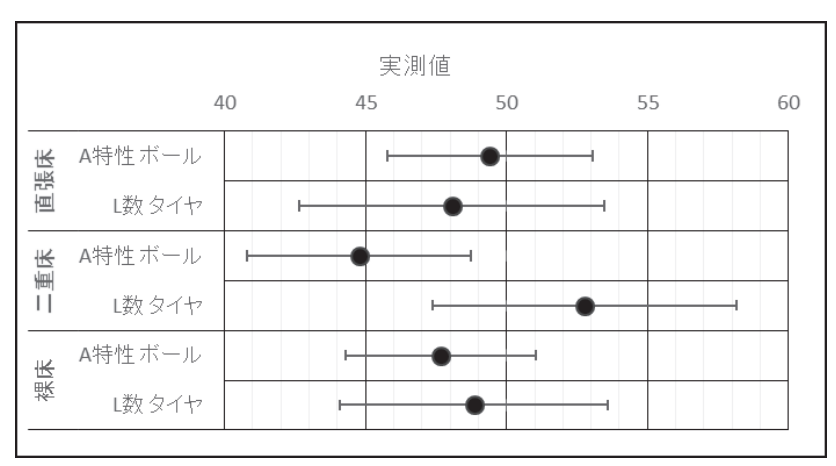

図 15 実測值の平均と $90 \%$ レンジ幅

また、図 15 に示す平均值を比べた場合、直張床および裸床にお いて、 L 数と $\mathrm{A}$ 特性は数值的にはほぼ等しい值を示すが、二重床の 場合は、タイヤ加振時の $\mathrm{L}$ 数のほうが 1 ランク（5dB）以上大きい值 を示寸傾向である。そのため、ボールの A 特性評価が同等性能であ ったとしても、タイヤ加振時の $\mathrm{L}$ 等級評価は床構造ごとに異なる性 能となる場合があり、評価基準が変わることによってタイヤ加振時 の $\mathrm{L}$ 等級評価とは性能の序列が変わる場合が出てくる可能性がある。 これは、衝撃力の変化に伴う床構造の非線形性が影響しているため であり、今後どの程度の衝撃力範囲で試験を行うべきなのか、実衝 撃源の衝撃力を含めて検討する必要がある。 


\section{5. まとめ}

実物件を対象に重量衝撃源の種類と評価量の関係について検討し た結果、以下の知見を得ることができた。

1）タイヤ加振時における性能が高い範囲では、L 等級評価では $63 \mathrm{~Hz}$ 帯域が決定周波数のままであるが、A 特性評価では $125 \mathrm{~Hz}$ 帯域以上の中高周波数成分の影響が強く表れ、両者の相関が低 下する。

2） ボール加振時とタッピングマシン加振時においては、性能の高 い範囲でも $\mathrm{L}$ 等級評価を決定する周波数帯域と $\mathrm{A}$ 特性評価の主 成分となる周波数帯域が同じであるため、 $\mathrm{L}$ 等級評価と A 特性 評価の対応が良い。

3）タイヤ加振時とボール加振時では、衝撃カレベルの周波数特性 の影響で A 特性評価の主成分となる周波数帯域が異なる。

4） タイヤ加振時の $\mathrm{L}$ 等級評価とボール加振時の $\mathrm{A}$ 特性評価の相関 は低く、特にボール加振時の $\mathrm{A}$ 特性評価は性能分解能が低下寸 る傾向にあり変動幅が狭くなる。

5）ボール加振時の $\mathrm{A}$ 特性評価とタイヤ加振時の $\mathrm{L}$ 等級評価では、 床構造に対する性能の序列が変化する場合がある。

例えば、ボール加振時の A 特性評価では、直張床・二重床共に $50 \mathrm{~dB}$ と同じ性能だったとしても、タイヤ加振時の $\mathrm{L}$ 等級評価で は、直張床は $\mathrm{L}_{\mathrm{rH}}-50$ 、二重床は $\mathrm{L}_{\mathrm{rH}}-55$ になる場合がある。

以上のように、タイヤ加振時の $\mathrm{L}$ 等級からボール加振時の $\mathrm{A}$ 特性 一変換するには、仕上げ構造や周波数特性を考慮する必要があるた め、それぞれの単一数值評価量を単純に置き換えて使うことは難し く、むしろボール加振時の $\mathrm{A}$ 特性評価はタイヤ加振時の $\mathrm{L}$ 等級評価 とは異なる性能を評価していると考えるほうが妥当である。

しかし、タイヤが提案された 1970 年代と現在では、居住者の音に 対する要求水準や、生活スタイルが変化していることを考慮すれば、 どちらの性能評価方法が重量床衝撃系騒音に対する居住者反応を適 切に表現しているか改めて検証する必要があり、床のどのような性 能を評価すべきか議論し決定すべきである。

一方、ここでは重量床衝撃系騒音を「子供の飛び跳ねに代表され る衝撃時間の比較的長い衝撃系騒音」と定義して考えたが、タイヤ 加振時の $\mathrm{L}$ 等級評価とボール加振時の $\mathrm{A}$ 特性評価が異なる性能を評 価していると考えるのであれば、ボール加振時の A 特性評価に関す る新たな技術体系を構築することを考えなければならない。そのた めには、ボール加振時の A 特性評価と居住者反応との対応を十分検 証し、その結果を踏まえた評価基準值を設定し、性能表示制度や各 種基準へ展開していく必要がある。

そこで、今後ボールを用いた A 特性評価が生活実感とどのように 対応するのか検討していくつもりである。

\section{参考文献}

1) 木村翔、大川平一郎、井上勝夫 : 重量床衝撃源の意義と望ましい衝撃力特 性について，日本建築学会技術報告集，第 1 号，pp199-202，1995. 12

2) 井上勝夫、安岡正人 : 床衝撃音に関わる居住者要求と遮音性能基準のあり 方, 日本建築学会大会学術講演梗概集, pp259-262, 2013.8

3) 井上勝夫、阿部今日子 : 集合住宅の居住者反応からみた重量床衝撃音遮断
性能の生活実感による表現方法の検討, 日本建築学会環境系論文集, 第 701 号, pp589-596, 2014.7

4))平松友孝: 音環境規準の AIJES 化概要とAIJES における床衝撃音の評価基 準の考え方，第 70 回音シンポジウム, pp16-19, 2012.3

5) 山本耕三：衝撃源の違いによる床衝撃音遮断特性，音響技術 No. 140 , pp45-52, 2007. 12

6) 大脇雅直、石丸岳史、久米智史、財満健史、近藤誠一、高倉史洋、山下恭 弘: 集合住宅の乾式二重床を標準重量衝撃源の衝撃力特性 (1)および衝撃力 特性 (2)で加振したときの床衝撃音レベルの特性に関する検討, 日本騒音 制御工学会研究発表会講演論文集, pp157-160, 2006.9

7 ) 漆戸幸雄、綿谷重規：コンクリート系集合住宅における衝撃力特性(2)を 持つ重量衝撃源による床衝撃音レベルについて, 日本建築学会学術講演梗 概集 D1，pp51-52，2003.9

8) 中澤真司、稲留康一：床衝撃音レベル等級と A 特性床衝撃音レベルの対応 に関する検討, 日本騒音制御工学会研究発表会講演論文集, pp73-76, 2011. 4

9)稲留康一、中澤真司：A 特性床衝撃音レベルのバンド合成等による算出方 法に関する検討，第 70 回音シンポジウム, pp9-15, 2012.3

10) 田中ひかり、田端淳：ゴムボールによる重量床衝撃音について-最大 $\mathrm{A}$ 特 性床衝撃音レベルをバンドレベルから求める方法-, 日本建築学会学術講 演梗概集 D1，pp211-212，2009.8

11) 漆戸幸雄、阿部将幸:オクターブバンド測定による A 特性床衝撃音レベル の測定および算出方法に関する検討（その 2 ），日本音響学会建築音響研 究会資料 AA2014-22，2014. 6

12) 日本建築学会編 : 建築物の遮音性能基準と設計指針（第二版），技報堂出 版, 1997.12

13) JIS A 1418-2:2000：建物の床衝撃音遮断性能測定方法、第 2 部：標準重 量衝撃源による方法、附属書 1

[2014 年 10 月 10 日原稿受理 2014 年 12 月 2 日採用決定］ 